\title{
Adherence in chronic hepatitis B: associations between medication possession ratio and adverse viral outcomes
}

Nicole L. Allard ${ }^{1,2^{*}}$, Jennifer H. MacLachlan ${ }^{1,2}$, Anouk Dev ${ }^{3}$, James Dwyer ${ }^{4}$, Geeta Srivatsa ${ }^{5}$, Timothy Spelman ${ }^{2,6}$, Alexander J. Thompson ${ }^{2,7}$ and Benjamin C. Cowie ${ }^{1,2}$

\begin{abstract}
Background: Antiviral therapy for chronic hepatitis B (CHB) is effective and can substantially reduce the risk of progressive liver disease and hepatocellular carcinoma but is often administered for an indefinite duration. Adherence has been shown in clinical trials to maximize the benefit of therapy and prevent the development of resistance, however the optimal threshold for predicting clinical outcomes has not been identified. The aim of this study was to analyse adherence using the medication possession ration (MPR) and its relation to virological outcomes in a large multi-centre hospital outpatient population, and guide development of an evidence-based threshold for optimal adherence.

Methods: Pharmacy and pathology records of patients dispensed CHB antiviral therapy from 4 major hospitals in Melbourne between 2010 and 2013 were extracted and analysed to determine their MPR and identify instances of unfavourable viral outcomes. Viral outcomes were classified categorically, with unfavourable outcomes including HBV DNA remaining detectable after 2 years treatment or experiencing viral breakthrough. The association between MPR and unfavourable outcomes was assessed according to various thresholds using ROC analysis and time-toevent regression.

\footnotetext{
* Correspondence: nicole.allard@mh.org.au

${ }^{1}$ WHO Collaborating Centre for Viral Hepatitis, Victorian Infectious Diseases Reference Laboratory, Royal Melbourne Hospital, at the Peter Doherty Institute for Infection and Immunity, Melbourne Victoria 3000, Australia ¿University of Melbourne, at the Peter Doherty Institute for Infection and Immunity, Victoria 3000, Australia

Full list of author information is available at the end of the article
}

(c) The Author(s). 2020 Open Access This article is licensed under a Creative Commons Attribution 4.0 International License, which permits use, sharing, adaptation, distribution and reproduction in any medium or format, as long as you give appropriate credit to the original author(s) and the source, provide a link to the Creative Commons licence, and indicate if changes were made. The images or other third party material in this article are included in the article's Creative Commons licence, unless indicated otherwise in a credit line to the material. If material is not included in the article's Creative Commons licence and your intended use is not permitted by statutory regulation or exceeds the permitted use, you will need to obtain permission directly from the copyright holder. To view a copy of this licence, visit http://creativecommons.org/licenses/by/4.0/. The Creative Commons Public Domain Dedication waiver (http://creativecommons.org/publicdomain/zero/1.0/) applies to the data made available in this article, unless otherwise stated in a credit line to the data. 


\begin{abstract}
(Continued from previous page)
Results: Six hundred forty-two individuals were included in the analysis. Median age was 46.6 years, $68 \%$ were male, $77 \%$ were born in Asia, and the median time on treatment was 27.5 months. The majority had favourable viral outcomes (91.06\%), with most having undetectable HBV DNA at the end of the study period. The most common unfavourable outcome was a rise of $<1$ log in HBV DNA (6.54\% of the total), while $2.49 \%$ of participants experienced viral breakthrough. Adherence was linearly associated with favourable outcomes, with increasing risk of virological breakthrough as MPR fell. Decreasing the value of MPR, at which a cut-point was taken, was associated with a progressively larger reduction in the rate of unfavourable event; from a $60 \%$ reduction under a cut-point of 1.00 to a $79 \%$ reduction when the MPR cut-point was set at 0.8 .

Conclusion: Lower adherence as measured using the MPR was strongly associated with unfavourable therapeutic outcomes, including virological failure. Optimising adherence is therefore important for preventing viral rebound and potential complications such as antiviral resistance. The evidence of dose-response highlights the need for nuanced interventions.
\end{abstract}

Keywords: Adherence, Antiviral therapy, Hepatitis B, Medication possession ratio

\section{Background}

Chronic hepatitis $\mathrm{B}(\mathrm{CHB})$ is responsible for increasing mortality and morbidity worldwide with liver cancer related mortality increasing globally, as the population living with hepatitis B infection ages, attributable mortality from other causes of death falls [1] . In 2015, the World Health Organisation (WHO) set ambitious targets for $\mathrm{CHB}$ including $80 \%$ of eligible people receiving treatment and a $65 \%$ reduction in attributable mortality by 2030 [2]. Measuring viral suppression in people living with $\mathrm{CHB}$ is one of the 10 core indicators in the monitoring and evaluation framework for viral hepatitis produced by the WHO, and a measure of retention in care and adherence to treatment for people receiving antiviral therapy $[2,3]$.

Antiviral treatment is effective at both preventing progressive liver damage and liver cancer in people living with $\mathrm{CHB}$ who have active viral replication and ongoing liver inflammation, or who have established cirrhosis $[4,5]$. Effective treatment results in a low or undetectable viral load, accompanied by normalization of hepatic transaminase levels (such as alanine aminotransferase, ALT). This can be achieved by using recommended first line antiviral agents entecavir or tenofovir, which are well tolerated, have high barriers to development of antiviral resistance, can reduce the risk of cancer by up to $75 \%$ over several years and can reverse established cirrhosis [4-6]. The optimal duration of antiviral treatment is yet to be defined, but treatment, once initiated, is most often considered to be indefinite or life-long [5]. Commencement of antiviral treatment is only a first step; as is the case for other chronic diseases requiring ongoing treatment and adherence to therapy is required to ensure effectiveness and to prevent viral breakthrough and the potential development of resistance [7].

Treatment adherence is a dynamic process in individuals and periods of poor adherence may result from temporary or more long-term disengagement from care due to competing social pressures, moving place of residence, difficulty attending clinical appointments and/or pharmacies, or interruption of supply of medication due to financial pressures, or day to day pressures that result in irregular dosing [8]. Poor adherence is also more common when the condition being treated is asymptomatic and the treatment regimen results in no overtly identifiable sense of improvement in health status [8-10]. Adherence is improved in people who have knowledge of their condition and in older individuals, and when the perceived severity of the condition is higher [8].

With new global goals to increase numbers of people with $\mathrm{CHB}$ on treatment, assessing and maximizing adherence will become an increasing challenge in all settings. A recent systematic review including 30 studies with different adherence measures estimated overall adherence to treatment in $\mathrm{CHB}$ with oral therapy was $75 \%$ and was similar in both high and low income settings [11]. Factors that have been shown to be related to poor adherence have included forgetting and change to routine, younger age, higher physician turnover and recent initiation of therapy [11-15]. Adverse reactions to medication can also result in poor adherence however antivirals for CHB have a low side effect profile and rarely adverse outcomes [16]. In a previous study we reported low adherence in 1026 participants was associated with age less than 35 years, inconsistency in clinical care and hospital site but not with type of oral antiviral prescribed [13].

Adherence can be measured by self-report, physician report, measurement of drug levels (dependent on assay availability), direct measurement with memory cap bottles and indirectly through pharmacy data [17]. Pharmacy adherence measures (PAMS) estimate medication in hand during an observed treatment period, can be easily calculated from pharmacy records and are less likely to have bias inherent in self-assessment or 
physician estimates, but represent only the maximal possible adherence during a time-period; actual administration of dispensed medications is not monitored [18]. Medication possession ratio (MPR) has been most commonly used as a measure of PAMS.

\section{Medication possession ratio (MPR) Number of pills dispensed \\ Number of days in time-period}

In the treatment of HIV with highly active antiretroviral therapy adherence, the MPR has been correlated with viral outcomes and mortality [18]. In the context of $\mathrm{CHB}$, an MPR cut-off to determine poor adherence of 0.90-0.95 has previously been arbitrarily chosen without clear reference to viral outcomes and/or mortality and morbidity $[12,19]$.

In Australia about $6 \%$ of all people living with $\mathrm{CHB}$ are receiving treatment with oral antivirals, predominantly entecavir $(45 \%)$ and tenofovir $(28 \%)$ [20, 21]. Antiviral medication has primarily been dispensed by public and private hospitals at a cost to the individual of US\$6-\$39 per 2 months of supply. There has been limited prescribing in the community context. An estimate of adherence or the number of people taking treatment who are virally suppressed or adherent to therapy has not yet been incorporated into the cascade of care at a national or jurisdictional level [20, 22].

The aims of this multicentre study were to evaluate virological outcomes in Australian setting, determine the proportion of patients with adequate viral suppression on treatment and to establish an evidence-based MPR definition of poor adherence based on the incidence of poor viral outcomes in patients receiving long term oral antiviral therapy for CHB.

\section{Methods}

This study was a retrospective analysis of records of patients dispensed antiviral monotherapy for $\mathrm{CHB}$ from 4 tertiary referral hospitals in Melbourne, Australia between 2010 and 2013. Pharmacy and pathology data were linked using hospital record number. Participants were included if they were prescribed antiviral monotherapy with $>3$ months of treatment and $\geq 2$ hepatitis $B$ virus DNA or viral load (HBV DNA) tests recorded in the hospital pathology service which was the minimum needed for classification of a viral outcome. The classification scheme for unfavourable or favourable viral outcomes is as presented in Table 1. As a sensitivity analysis, non-transient rise was classified as a favourable outcome and the impact assessed (see Appendix).

MPR values were calculated from records of medication dispensed from the first pharmacy visit to the date immediately after or at the same time as the event was
Table 1 Viral outcome categories for HBV treatment

\begin{tabular}{|c|c|}
\hline \multicolumn{2}{|c|}{ Favourable viral outcomes: } \\
\hline $\begin{array}{l}\text { Fully } \\
\text { suppressed }\end{array}$ & $\begin{array}{l}\text { HBV DNA undetectable for study period } \\
\text { OR } \\
\text { HBV DNA became undetectable with no further rise }\end{array}$ \\
\hline $\begin{array}{l}\text { Adequate viral } \\
\text { suppression }\end{array}$ & $\begin{array}{l}\text { Where treatment duration was }<2 \text { years, HBV DNA } \\
\text { decreased }>1 \log 10\end{array}$ \\
\hline Transient rise & $\begin{array}{l}\text { a single instance of increased DNA level }<150 \mathrm{IU} / \mathrm{ML} \\
\text { with return to undetectable at next test }\end{array}$ \\
\hline \multicolumn{2}{|c|}{ Unfavourable viral outcomes: } \\
\hline $\begin{array}{l}\text { Not } \\
\text { suppressed }\end{array}$ & Detectable HBV DNA after 2 years on treatment \\
\hline $\begin{array}{l}\text { Non-transient } \\
\text { rise }\end{array}$ & $\begin{array}{l}<1 \text { log rise in HBV DNA which was not a transient } \\
\text { rise }\end{array}$ \\
\hline $\begin{array}{l}\text { Viral } \\
\text { breakthrough }\end{array}$ & $\begin{array}{l}\geq 1 \times \log _{10} \text { rise in HBV DNA level from nadir which } \\
\text { was not a transient rise }\end{array}$ \\
\hline
\end{tabular}

observed, as pharmacy pick up dates did not always align with date of pathology tests. For those who were fully suppressed throughout the time-period, the MPR was calculated for the whole observed period. Participants could have more than one event recorded with separate calculations made of cumulative MPR prior to each event.

\section{Statistical analyses}

Categorical variables were summarised using frequency and percentage. Continuous variables were summarised using mean and standard deviation (SD) or median and inter-quartile range (IQR) as appropriate. As individual patients were permitted to contribute multiple unfavourable outcomes across the observation period, an Andersen-Gill time-to-multiple event model was used to study associations between MPR and unfavourable viral outcomes. Hazard proportionality was assessed via analysis of scaled Schoenfeld residuals. Results are presented as the individual hazard ratio of unfavourable for each MPR cut off category $(\geq 0.80 ;>0.90 ;>0.95 ; 1.0 ;>1.05)$. All multivariable models were assessed for interactions between explanatory variables. MPR values of $<1$ indicated inadequate supply for the time period or less than one tablet per day with < $0.80=80 \%$ tablets per number of days and $0.9090 \%$ etc. Values $>1.0$ or greater $>1.05$ indicated over supply of pills dispensed per number of days in the time period. MPR was analysed with Youden analyses as a continuous variable to ascertain a possible cut off point. Further analyses of previously used categorical values of MPR to identify performance of those values of MPR in discriminating the outcome variables and was performed with receiver operating characteristic (ROC) curve, sensitivity, specificity and positive and negative predictive values (PPV and NPV). For all analyses, $p<0.05$ was considered significant. All analyses were conducted in R ( $\mathrm{R}$ Foundation for Statistical Computing, Vienna, Austria). 
Ethics approval was granted by Human Research Ethics Committees at Melbourne Health, Monash Health, Western Health and St. Vincent's Hospital to access de identified pharmacy records and internal patient management software for demographic information.

\section{Results}

\section{Patient characteristics}

Six hundred forty-two individuals' records were included in the final analysis representing 1234 patient-years of antiviral treatment. Three hundred eighty-four individuals were excluded for insufficient data $(<2$ viral loads recorded in the hospital pathology services during the period on treatment). There were no differences in age, sex distribution or adherence pattern in the excluded records (data not shown). The median time on treatment during the study period was 27.5 months (IQR 13.532.9 ) and the median number of viral loads performed 4 (IQR 3-6). Most (91.7\%) of the patients on antiviral medication were born overseas, with $77 \%$ of the total born in Asia (Table 2). In total, 550 patients (85.7\%) were on first-line oral antiviral therapies (either entecavir $0.5 \mathrm{mg}$ or tenofovir $300 \mathrm{mg}$ ).

\section{Viral outcomes}

Favourable viral outcomes were seen in $91.06 \%$ of individuals (Table 3 ). The majority either were undetectable for the full treatment period $(48.85 \%)$ or became undetectable $(26.25 \%)$ by the end of the treatment period. Of those with unfavourable outcomes (8.94\% of the total), the most common was a non-transient rise $(6.54 \%$ of the total), while 17 (2.54\%) experienced viral breakthrough. Forty participants had 2 events recorded during treatment period MPR was calculated for the period prior or up to each event. The proportion of individuals with favourable outcomes was similar across all drugs used (75.00$92.31 \%$, Table 2), with no evidence of difference in the proportion for entecavir vs. tenofovir $(p=0.30)$ or for first line therapy vs. older drugs $(p=0.38)$.

Table 2 Patient characteristics

\begin{tabular}{lll}
\hline & Number(\%) & Median age (IQR) \\
\hline $\begin{array}{l}\text { Gender } \\
\text { Male }\end{array}$ & $441(68.69)$ & $46.55(38.00-56.31)$ \\
Female & $201(31.31)$ & $46.66(37.00-56.86)$ \\
Region of birth & & \\
Asia & $496(77.26)$ & $46.00(31.00-55.09)$ \\
Europe & $49(7.63)$ & $61.00(53.00-68.39)$ \\
Australia & $45(7.01)$ & $44.00(31.00-55.60)$ \\
Africa & $34(5.30)$ & $40.76(33.52-47.34)$ \\
Other & $10(1.56)$ & $45.00(53.00-59.39)$ \\
Not recorded & $8(1.25)$ & \\
\hline
\end{tabular}

\section{MPR and association with virological outcome}

An MPR of $<1.0$ was seen in 346 individuals (53.89\% of the total). In the time to event analysis, the hazard of unfavourable outcomes was increased with a lower MPR (Table 4). The proportion of individuals experiencing unfavourable outcomes over time are presented in Fig. 1a-d which demonstrate the differential outcomes according to MPR cut-off. An MPR of $\geq 1.0$ was associated with a $60 \%$ reduction in risk of unfavourable outcomes compared to those with an MPR of $<1.00$, while an $\mathrm{MPR} \geq 0.80$ reduced risk by $79 \%$ compared to an MPR of $<0.80$. No evidence was seen of an association between an MPR $\geq 1.05$ and viral outcomes.

The empirical cut-point on the Youden analysis for MPR was 0.98 , with sensitivity and specificity at that threshold of $41 \%$ and area under ROC 0.41 . Further analyses of sensitivity, specificity, PPV and NPV according to MPR categories are presented in Table 5.The specificity demonstrates the ability of MPR to predict unfavourable outcomes increased with higher MPR cut off points, however PPV was low across all MPR cut-point thresholds, which reflects the finding that the majority of individuals with an MPR below threshold did not experience an unfavourable viral outcome. NPV, conversely, was $>75 \%$ for all thresholds.

In the sensitivity analysis assessing transient rises as an unfavourable outcome, decreasing MPR was associated with a greater hazard ratio for non-transient rises (0.008) but not transient rises (See Appendix). Including transient rises had the impact of increasing the hazard ratios for unfavourable events above the cut point.

\section{Discussion}

This is the largest study to date assessing the association between MPR and viral outcomes across multiple sites with single oral dose antiviral treatment for $\mathrm{CHB}$ using real world data $[14,19,23]$. Previous studies have evaluated viral outcomes with self-report or individual hospital cohorts [14, 16]. Approximately $80 \%$ of patients achieved suppression or were suppressed during the study period consistent with other studies [14, 24]. Lower MPR values were associated with unfavourable viral outcomes in people taking antiviral medication for $\mathrm{CHB}$ with an increased risk of viral breakthrough.

Values used for defining 'poor adherence' have previously been arbitrary and have ranged from 80 to $95 \%$ [7, 13, 19, 25-27], with a small study that examined entecavir and viral outcomes with a proposed cut-off of less than 90\% [7]. This study illustrates that the hazard ratio for unfavourable outcomes increases with decreasing medication taking and that previous use of thresholds such as 0.90 are supported by evidence of a greater risk of events but are not a true cut-off points to define adherence based on viral outcomes. While self- 


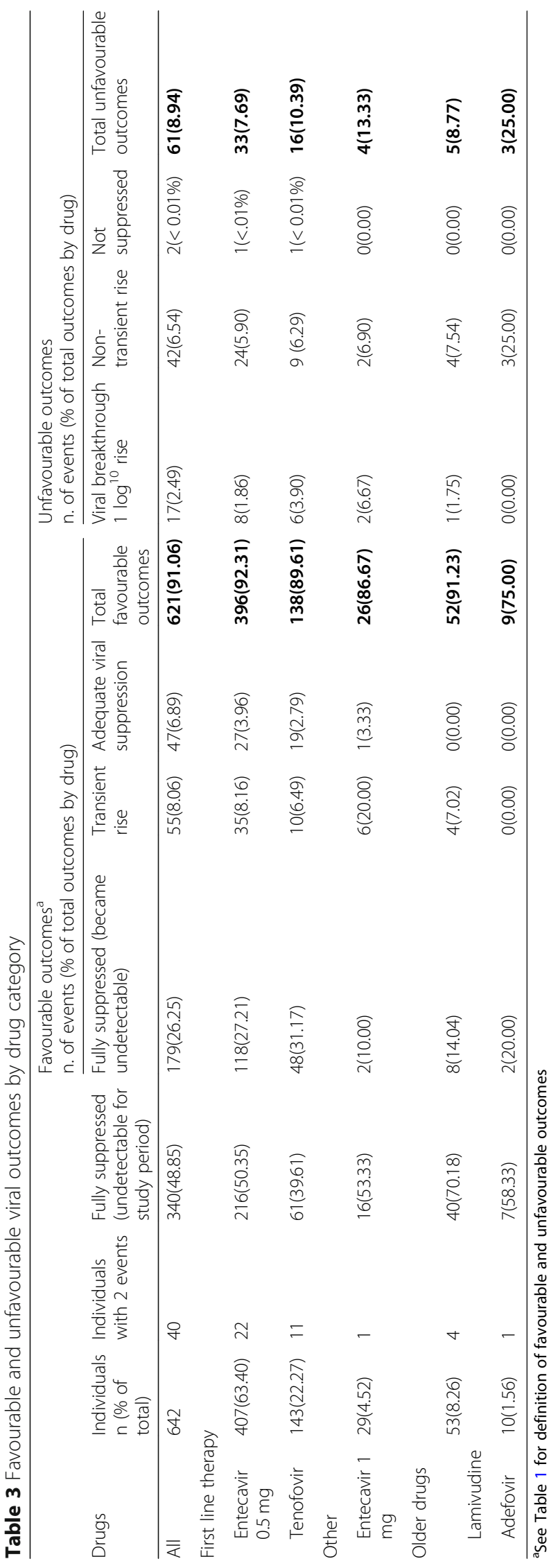


Table 4 Hazard ratio for unfavourable events for each MPR cut off threshold, and interpretation of risk reduction of unfavourable events

\begin{tabular}{lll}
\hline MPR threshold comparison & $\begin{array}{l}\text { Hazard ratio for unfavourable events with } \\
\text { MPR above threshold }(95 \% \mathrm{Cl}) p \text {-value }\end{array}$ & $\begin{array}{l}\text { Interpretation of risk reduction of unfavourable } \\
\text { events with MPR above threshold }\end{array}$ \\
\hline$\geq 0.80$ vs $<0.80$ & $0.214(0.12-0.37)<0.001$ & $79 \%$ \\
$\geq 0.90$ vs $<0.90$ & $0.292(0.17-0.50)<0.001$ & $71 \%$ \\
$\geq 0.95$ vs $<0.95$ & $0.334(0.20-0.57)<0.001$ & $67 \%$ \\
$\geq 1.00$ vs $<1.00$ & $0.398(0.22-0.73) 0.003$ & $60 \%$ \\
$\geq 1.05$ vs $\leq 1.05$ & $0.600(0.29-1.44) 0.287$ & No evidence of association \\
\hline
\end{tabular}

reported patient adherence has recently also been shown to be associated viral outcomes, there was no clear dose response or increase in relative risk of viral breakthrough with increased doses reported to be missed [14], this finding is likely due to social desirability bias. Self-report, in a clinical context, has the advantage of a simple question to assess adherence however by using MPR or combining adherence measures in clinical practice it is possible to better assess the risk of unfavourable viral outcomes and advise patients how to mitigate that risk.
A small number of patients in this study remained on less effective therapies despite universal access to newer antiviral therapy as is also observed in national prescribing data for Australia [21]. Participants on older regimes did not have increased number of unfavourable outcomes despite the lower barrier to resistance observed with these agents. This may in part be due to small numbers, and possible selection bias as those remaining on older agents are likely to be those who had achieved and maintained virological suppression.

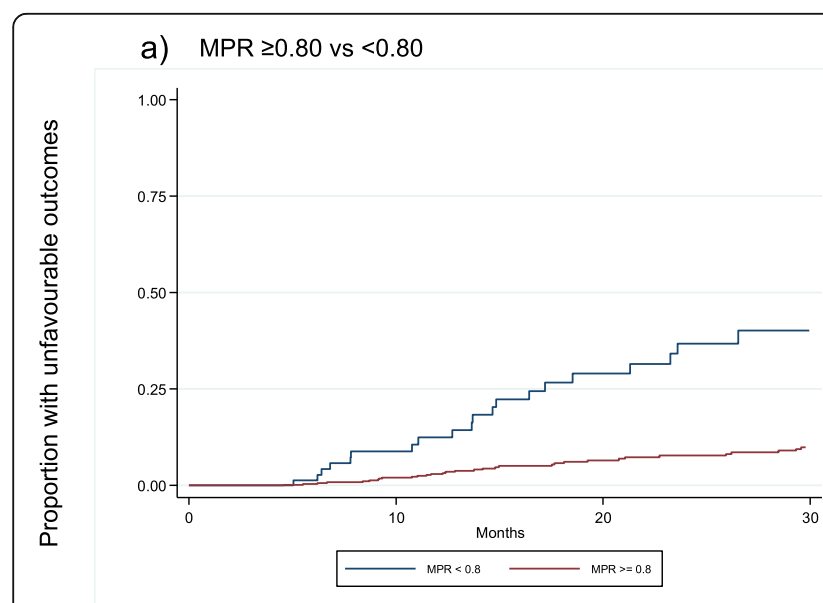

c) MPR $\geq 0.95$ vs $<0.95$

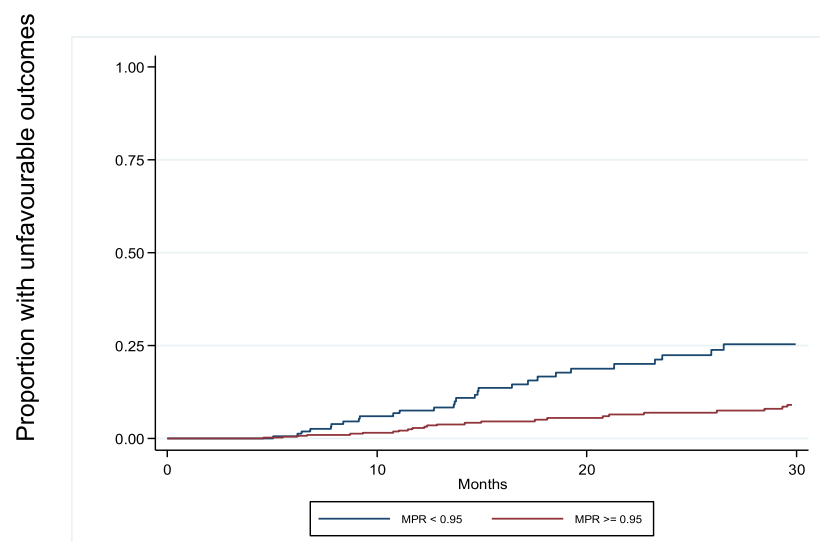

b) MPR $\geq 0.90$ vs $<0.90$

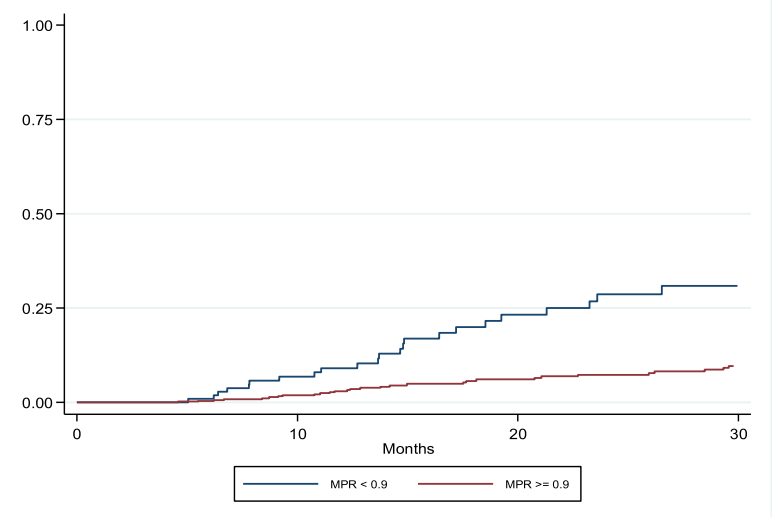

d) MPR $\geq 1.00$ vs $<1.00$

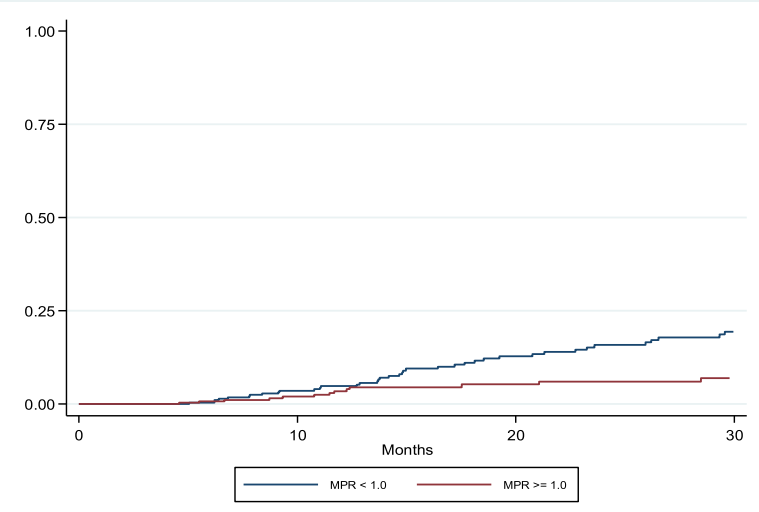

Fig. 1 a-d Proportion of individuals experiencing unfavourable outcomes over time according to MPR cut-off points 
Table 5 Test parameters for MPR cut-offs in detecting unfavourable viral outcomes

\begin{tabular}{llllllll}
\hline MPR category & $\begin{array}{l}\text { Number of individuals } \\
\text { in category }\end{array}$ & $\begin{array}{l}\text { Number of individuals with } \\
\text { unfavourable outcomes }\end{array}$ & $\begin{array}{l}\text { Sensitivity \% } \\
(95 \% \mathrm{Cl})\end{array}$ & $\begin{array}{l}\text { Specificity \% } \\
(95 \% \mathrm{Cl})\end{array}$ & $\begin{array}{l}\mathrm{PPV} \% \\
(95 \% \mathrm{Cl})\end{array}$ & $\begin{array}{l}\mathrm{NPV} \% \\
(95 \% \mathrm{Cl})\end{array}$ & $\begin{array}{l}\text { ROC } \\
(95 \% \mathrm{Cl} \text { area }\end{array}$ \\
\hline$<0.80$ & 97 & 21 & $65.6(52.3-77.3)$ & $12.2(9.8-15.1)$ & $6.8(4.9-9.2)$ & $78.4(68.8-86.1)$ & $0.39(0.33-0.45)$ \\
$<0.90$ & 137 & 24 & $60.7(47.3-72.9)$ & $18.2(15.2-21.5)$ & $6.8(4.9-9.2)$ & $82.5(75.1-88.4)$ & $0.39(0.33-0.46)$ \\
$<0.95$ & 197 & 31 & $49.2(36.1-36.1)$ & $26.7(23.3-30.4)$ & $6.2(4.2-8.7)$ & $84.3(78.4-89.1)$ & $0.38(0.31-0.45)$ \\
$<1.00$ & 346 & 44 & $27.9(17.1-40.8)$ & $48.6(44.6-52.6)$ & $5.1(3.0-8.0)$ & $87.3(83.3-90.6)$ & $0.38(0.32-0.44)$ \\
$<1.05$ & 510 & 52 & $14.8(7.0-26.2)$ & $73.8(70.1-77.2)$ & $5.2(2.4-9.7)$ & $89.8(86.8-92.3)$ & $0.44(0.39-0.49)$ \\
\hline
\end{tabular}

${ }^{a}$ The average of sensitivity and specificity for the binary MPR cut-point being tested

PPV Positive predictive value, NPV Negative predictive value, $R O C$ receiver operating characteristic

This study is limited by retrospective clinical data that are heterogeneous: the number of pharmacy visits, amount of drug dispensed at each visit and number of viral loads performed over the time-period all varied. No measure of patient adherence is without limitations [18]. Medication possession ratio calculated over any timeperiod masks variations in adherence: a period of stockpiling followed by a period of poor adherence, losing medication or conversely a period of poor adherence followed by regular medication taking. Calculation of MPR accounts for medication picked up from a pharmacy but does not equate to actual pill taking [18]. Oral antiviral therapy for the treatment of $\mathrm{CHB}$ was mainly dispensed via the hospital system during the time period so it is unlikely MPR was underestimated. It is possible that viral load test results could have been performed outside the hospital pathology service and not all viral events during the treatment period are captured.

The analysis was performed using real word data with different types of medication that may have different efficacies when evaluating viral suppression. Host immunological changes causing viral suppression, or the development of antiviral resistance while on medication could have influenced findings of undetectable viral load or viral breakthrough over and above medication adherence. This study was not powered to detect association with MPR and adverse outcomes including mortality as has been previously described in HIV therapy; this is in part due to the differing natural history of HBV and HIV, with very different time lines to attributable mortality off treatment.

Poor adherence is a challenge for health systems and all chronic diseases and there are few interventions that have been successful in improving adherence $[17,28]$. Long term antiviral treatment for hepatitis B requires regular assessment of adherence by clinicians in a nonjudgmental atmosphere [17]. Health systems need to enable ease of supply of medication, affordability of treatment and consistent practitioners that have a chance to build trust, knowledge and assist when they have challenges that may impact on adherence [13, 29].

Maximising outcomes for people living with $\mathrm{CHB}$ must include regular assessment of adherence and a focus on maximising good outcomes for people living with $\mathrm{CHB}$. Adherence interventions have been rarely trialled in $\mathrm{CHB}$ and there is a need to explore further barriers faced by individuals and then design and implement appropriate interventions to assist the one in every five patients who have poor adherence [13].

\section{Conclusion}

This study demonstrated that MPR is a useful measure to use to assess risk of poor viral outcomes. There is evidence for the $90 \%$ threshold commonly used to assess adherence, however there is a dose response relationship that must be considered in risk reduction. As we move towards increasing the number of people on treatment both in Australia and worldwide, evaluating hepatitis B viral suppression in multi centre or population-level data, and trialling systems improvement to enhance adherence will be increasingly important for achieving better health outcomes for people living with chronic hepatitis B.

\section{Appendix}

A further analysis was undertaken with the alternate classification of transient rises as an unfavourable outcome, as below:

Table 6 Viral outcome categories for HBV treatment used in sensitivity analysis

Favourable viral outcomes:

$\begin{array}{ll}\text { Fully suppressed } & \text { HBV DNA undetectable for study period } \\ & \text { OR } \\ & \text { HBV DNA became undetectable with } \\ & \text { no further rise }\end{array}$

Adequate viral Where treatment duration was $<2$ years, suppression HBV DNA decreased $>1 \log 10$

Unfavourable viral outcomes:

Not suppressed Detectable HBV DNA after 2 years on treatment

Non-transient rise $\quad<1$ log rise in HBV DNA which was not a transient rise

Viral breakthrough $\quad \geq 1 \times \log _{10}$ rise in HBV DNA level from nadir which was not a transient rise

Transient rise $\quad$ a single instance of increased DNA level $<150$ IU/ML with return to undetectable at next test 
Table 7 Hazard ratio for unfavourable events for each MPR cut off threshold, and interpretation of risk reduction of unfavourable events, using alternate classifications presented in Table 6 in Appendix (sensitivity analysis)

\begin{tabular}{lllll}
\hline MPR category & $\begin{array}{l}\text { Number of individuals } \\
\text { in category }\end{array}$ & $\begin{array}{l}\text { Number of individuals } \\
\text { with unfavourable } \\
\text { outcomes }\end{array}$ & $\begin{array}{l}\text { Hazard ratio for unfavourable events } \\
\text { with MPR above threshold }(95 \% \mathrm{Cl}) \\
p \text {-value }\end{array}$ & $\begin{array}{l}\text { Interpretation of risk reduction of } \\
\text { unfavourable events with MPR } \\
\text { above threshold }\end{array}$ \\
\hline$<0.80$ & 97 & 11 & $0.08(0.03-0.21)<0.001$ & $92 \%$ \\
$<0.90$ & 137 & 12 & $0.11(0.04,0.30)<0.001$ & $89 \%$ \\
$<0.95$ & 197 & 13 & $0.16(0.05,0.45) 0.001$ & $84 \%$ \\
$<1.00$ & 346 & 16 & $0.26(0.07,0.91) 0.034$ & $74 \%$ \\
$<1.05$ & 510 & 18 & $0.31(0.04,2.33) 0.254$ & No evidence of association \\
\hline
\end{tabular}

\section{Abbreviations}

CHB: Chronic hepatitis B; Cl: Confidence interval; HBV: Hepatitis B virus; HBV: DNA Hepatitis B virus DNA or viral load; HIV: Human immunodeficiency virus; IQR: Inter-quartile range; MPR: Medication possession ratio; NPV: Negative predictive value; PPV: Positive predictive value; ROC: Receiver operating characteristic; SD: Standard deviation

\section{Acknowledgments}

Not applicable.

\section{Authors' contributions}

NA conceived and designed the analysis, collected the data; performed preliminary analysis and wrote the paper, TS performed the final analysis and reviewed the paper, JM wrote and reviewed the paper, JD, GS, AT and AD contributed data and revised the final paper, BC conceived of the study and reviewed the paper. All authors have read and approved the manuscript in the final version.

\section{Funding}

NA was supported by an Australian Post Graduate award scholarship as part of her PhD. The study was supported by the Royal Melbourne Hospital Lottery Grant.

\section{Availability of data and materials}

The datasets used and/or analysed during the current study are available from the corresponding author on reasonable request.

\section{Ethics approval and consent to participate}

Ethics approval was granted by HREC committees at Melbourne Health, Western Hospital, St Vincent's Hospital and Monash Health.

\section{Competing interests}

$N A, B C$ JD, JM, TS and GS have no competing interests to declare. AD has received money for Speaking Services: Bayer Pharmaceuticals, Bristol Myers Squibb Pharmaceuticals, Gilead Sciences, Janssen Pharmaceuticals, Merck Australia, Roche Pharmaceuticals, W.L Gore and Associates. Consultant for: Bayer Pharmaceuticals, Merck Australia. Advisory board membership: ABBVIE Pharmaceuticals, Bayer Pharmaceuticals. Research Support: Bayer Pharmaceuticals, Bristol Myers Squibb Pharmaceuticals, Gilead Sciences, Merck Australia, Roche Pharmaceuticals.

AT is an Advisory board member: AbbVie, Bristol-Myers Squibb, Gilead Sciences, Janssen, Merck Sharp \& Dohme and Roche Diagnostics. Speaker: AbbVie, Bristol-Myers Squibb, Gilead Sciences, and Merck Sharp \& Dohme. Principal investigator: Bristol-Myers Squibb, Gilead Sciences, Janssen, Merck Sharp \& Dohme, Roche and Spring Bank, Arrowhead. Receives research/grant support: AbbVie, Bristol-Myers Squibb, Gilead Sciences, Merck Sharp \& Dohme.

\section{Author details}

'WHO Collaborating Centre for Viral Hepatitis, Victorian Infectious Diseases Reference Laboratory, Royal Melbourne Hospital, at the Peter Doherty Institute for Infection and Immunity, Melbourne Victoria 3000, Australia. ¿University of Melbourne, at the Peter Doherty Institute for Infection and Immunity, Victoria 3000, Australia. ${ }^{3}$ Department of Gastroenterology, Monash Health, and Monash University, Victoria 3168 Clayton, Australia. ${ }^{4}$ Mercy
Hospital for Women, Victoria 3084, Australia. ${ }^{5}$ Western Health and Footscray Hospital, Footscray, Victoria 3011, Australia. ${ }^{6}$ Burnet Institute, Melbourne 3000, Australia. ${ }^{7}$ St. Vincent's Hospital, Melbourne 3000, Australia.

Received: 22 December 2019 Accepted: 11 March 2020 Published online: 07 May 2020

\section{References}

1. Stanaway JD, Flaxman AD, Naghavi M, Fitzmaurice C, Vos T, Abubakar I, et al. The global burden of viral hepatitis from 1990 to 2013: findings from the global burden of disease study 2013. Lancet. 2016;388(10049): 1081-8.

2. World Health Organization. Global Health Sector Strategy on Viral Hepatitis, 2016-2021. Geneva: World Health Organization; 2016.

3. World Health Organization. Monitoring and Evaluation for Viral Hepatitis B and C: recommended indicators and framework. Geneva: World Health Organization; 2016.

4. Papatheodoridis GV, Lampertico P, Manolakopoulos S, Lok A. Incidence of hepatocellular carcinoma in chronic hepatitis B patients receiving nucleos(t)ide therapy: a systematic review. J Hepatol. 2010;53(2):348-56.

5. Terrault NA, Bzowej NH, Chang KM, Hwang JP, Jonas MM, Murad MH. AASLD guidelines for treatment of chronic hepatitis B. Hepatology. 2015; 63(1):261.

6. European Association for the Study of the Liver. EASL 2017 clinical practice guidelines on the management of hepatitis B virus infection. J Hepatol. 2017;67(2):370-98

7. Kamezaki H, Kanda T, Arai M, Wu S, Nakamoto S, Chiba T, et al. Adherence to medication is a more important contributor to viral breakthrough in chronic hepatitis B patients treated with entecavir than in those with lamivudine. Int J Med Sci. 2013;10(5):567-74

8. Kardas P, Lewek P, Matyjaszczyk M. Determinants of patient adherence: a review of systematic reviews. Front Pharmacol. 2013:4:91.

9. Osterberg L, Blaschke T. Adherence to medication. N Engl J Med. 2005; 353(5):487-97.

10. Ingersoll KS, Cohen J. The impact of medication regimen factors on adherence to chronic treatment: a review of literature. J Behav Med. 2008; 31(3):213-24.

11. Ford $N$, Scourse $R$, Lemoine $M$, Hutin $Y$, Bulterys $M$, Shubber $Z$, et al. Adherence to Nucleos(t)ide analogue therapies for chronic hepatitis $B$ infection: a systematic review and meta-analysis. Hepatol Commun. 2018; 2(10):1160-7.

12. Chotiyaputta W, Peterson C, Ditah FA, Goodwin D, Lok AS. Persistence and adherence to nucleos(t)ide analogue treatment for chronic hepatitis B. J Hepatol. 2011;54(1):12.

13. Allard N, Dev A, Dwyer J, Srivatsa G, Thompson A, Cowie B. Factors associated with poor adherence to antiviral treatment for hepatitis B. J Viral Hepat. 2016;24(1):53.

14. Sheppard-Law S, Zablotska-Manos I, Kermeen M, Holdaway S, Lee A, Zekry A, et al. Factors associated with HBV virological breakthrough. Antivir Ther 2016;22(1):53-60.

15. Peng J, Yin J, Cai S, Yu T, Zhong C. Factors associated with adherence to nucleos(t)ide analogs in chronic hepatitis B patients: results from a 1-year follow-up study. Patient Prefer Adherence. 2015;9:41-5. 
16. Fung J, Seto WK, Lai CL, Yuen MF. Extrahepatic effects of nucleoside and nucleotide analogues in chronic hepatitis B treatment. J Gastroenterol Hepatol. 2014;29(3):428-34.

17. Sabaté E. Adherence to long-term therapies: evidence for action. Geneva: World Health Organization; 2003.

18. McMahon JH, Jordan MR, Kelley K, Bertagnolio S, Hong SY, Wanke CA, et al. Pharmacy adherence measures to assess adherence to antiretroviral therapy: review of the literature and implications for treatment monitoring. Clin Infect Dis. 2011;52(4):493-506.

19. Lieveld Fl, van Vlerken LG, Siersema PD, van Erpecum KJ. Patient adherence to antiviral treatment for chronic hepatitis B and C: a systematic review. Ann Hepatol. 2013;12(3):380-91.

20. Allard NL, MacLachlan JH, Cowie BC. The cascade of care for Australians living with chronic hepatitis B: measuring access to diagnosis, management and treatment. Aust N Z J Public Health. 2015:39(3):255-9.

21. MacLachlan JH, Cowie BC. Hepatitis B mapping project: estimates of chronic hepatitis $B$ prevalence, diagnosis, monitoring and treatment by primary health network - National Report 2014/15. Darlinghurst: Australasian Society for HIV, Viral Hepatitis and Sexual Health Medicine, and Victorian Infectious Diseases Reference Laboratory, Peter Doherty Institute for Infection and Immunity; 2016.

22. Australian Government Department of Health. Second National Hepatitis B Strategy 2014-2017. Canberra: Australian government department of health; 2014. [updated 7 July]. Available from: http://www.health.gov.au/internet/ main/publishing.nsf/Content/ohp-bbvs-hepb.

23. Hilleret MN, Larrat S, Stanke-Labesque F, Leroy V. Does adherence to hepatitis B antiviral treatment correlate with virological response and risk of breakthrough? J Hepatol. 2011;55(6):1468-9 author reply 9-70.

24. Pol S, Lampertico P. First-line treatment of chronic hepatitis B with entecavir or tenofovir in 'real-life' settings: from clinical trials to clinical practice. J Viral Hepat. 2012;19(6):377-86.

25. Chotiyaputta W, Hongthanakorn C, Oberhelman K, Fontana RJ, Licari T, Lok AS. Adherence to nucleos(t)ide analogues for chronic hepatitis B in clinical practice and correlation with virological breakthroughs. J Viral Hepat. 2012; 19(3):205-12.

26. Berg T, Marcellin P, Zoulim F, Moller B, Trinh H, Chan S, et al. Tenofovir is effective alone or with emtricitabine in adefovir-treated patients with chronic-hepatitis B virus infection. Gastroenterology. 2010;139(4):1207-17.

27. van Vlerken LG, Arends P, Lieveld FI, Arends JE, Brouwer WP, Siersema PD, et al. Real life adherence of chronic hepatitis B patients to entecavir treatment. Dig Liver Dis. 2015;47(7):577-83.

28. Haynes RB, Ackloo E, Sahota N, McDonald HP, Yao X. Interventions for enhancing medication adherence. Cochrane Database Syst Rev. 2008;2: CD000011.

29. Dahl TF, Cowie BC, Biggs BA, Leder K, MacLachlan JH, Marshall C. Health literacy in patients with chronic hepatitis B attending a tertiary hospital in Melbourne: a questionnaire based survey. BMC Infect Dis. 2014;14:537.

\section{Publisher's Note}

Springer Nature remains neutral with regard to jurisdictional claims in published maps and institutional affiliations.

Ready to submit your research? Choose BMC and benefit from:

- fast, convenient online submission

- thorough peer review by experienced researchers in your field

- rapid publication on acceptance

- support for research data, including large and complex data types

- gold Open Access which fosters wider collaboration and increased citations

- maximum visibility for your research: over $100 \mathrm{M}$ website views per year

At $\mathrm{BMC}$, research is always in progress.

Learn more biomedcentral.com/submissions 